\title{
Firm Heterogeneity and EXPort Activity of European Firms: A QuANTILE Analysis
}

\author{
HETEROGENEIDAD EMPRESARIAL Y ACTIVIDAD EXPORTADORA DE LAS \\ EMPRESAS EUROPEAS: UN ANÁLISIS DE REGRESIÓN CUANTÍLICA \\ Vicente Orts \\ orts@uji.es \\ Universidad Jaume I \\ Josep Martí \\ arnauj@uji.es \\ Universidad Jaume I
}

Recibido: abril de 2018; aceptado: junio de 2018

\section{ABSTRACT}

This paper examines the extent to which firms' characteristics are related to export activity behaviour. Using a dataset comprised of harmonized and detailed firm-level data from six European countries (Austria, France, Germany, Italy, Spain and United Kingdom) for the period 2007-2009 (EFICE dataset), we analyse the effects of firms' characteristics on two different measures of export activity: export intensity and market scope. Firstly, we estimate OLS regressions to analyse this relationship. Our empirical results show that there is a positive relationship between firms' characteristics and export activity. Secondly, quantile regressions are performed in order to observe whether there are any heterogeneous effects along the conditional distribution of the two measures of export activity. The quantile regressions reveal the existence of heterogeneous effects and nonlinearities among firms' characteristics and both export intensity and market scope. Moreover, the quantile analysis also shows that, for some cases, the effects of firms' characteristics on export intensity and market scope differ greatly.

Keywords: European Firms; Firm Heterogeneity; Export Intensity; Market Scope; Quantile Regression. 


\section{RESUMEN}

El artículo analiza en qué medida las características de las empresas se relacionan con el comportamiento de la actividad exportadora. Utilizando una base de datos detallados y armonizados de empresas de seis países europeos (Austria, Francia, Alemania, Italia, España y Reino Unido) para el perīodo 2007-2009 (base de datos EFIGE) se analizan los efectos de las características de las empresas sobre dos medidas diferentes de la actividad exportadora: intensidad exportadora y cobertura de mercado. En primer lugar, estimamos las regresiones por MCO para analizar esta relación. Nuestros resultados empíricos muestran que existe una relación positiva entre las variables. En segundo lugar, se aplican regresiones cuantílicas para determinar si existen efectos heterogéneos en la distribución condicional de las dos medidas de la actividad exportadora. Las regresiones cuantílicas revelan la existencia de efectos heterogéneos y no lineales y, además, muestra que, para algunos casos, los efectos de las características de las empresas en la intensidad exportadora y la cobertura de mercado, difieren considerablemente.

Palabras clave: Empresas europeas; Heterogeneidad empresarial; Intensidad exportadora; Cobertura de mercado; Regresiōn cuantílica.

JEL codes: F10; F12; F14; F23; C81; D22. 


\section{INTRODUCTION ${ }^{1}$}

According to the World Trade Organization, ${ }^{2}$ the volume of world exports quadrupled between 1980 and 2010, reaching \$9.7 trillion, in spite of the negative effects of the last financial crisis on world trade. As a result, international trade accounts for a major share of GDP in many countries, and export activity and its determinants become increasingly relevant to analyse aspects such as economic growth and development, improvements in productivity, employment and wages, from both the academic point of view and that of policymakers. Thus, according to a recent report by the Competitiveness Research Network of the European System of Central Banks, in Europe, restoring external competitiveness has been at the core of the European policy agenda, given that a very substantial share of the European economic activity in the manufacturing sectors is related to exports. ${ }^{3}$

This significant increase in the volume of trade and policy interest has been accompanied by new theoretical developments that shift the focus of research on international trade away from industries and countries towards firms and products (Bernard et al., 2012). In the late nineties, the availability of large amounts of microdata led to the appearance of an important number of empirical works that related firms' characteristics and their activity in international trade. ${ }^{4}$ These studies soon drew up a set of stylized facts that were difficult to reconcile with explanatory models of trade based on representative firms. The empirical evidence reveals that only a small fraction of the firms that are active in an industry are exporters, even if industry is defined in a narrow way. Moreover, only a few of them export a wide range of products and do so to a large number of markets, that is, they have large product and market scope. Furthermore, this empirical research also highlights the existence of a systematic relationship between firm characteristics and their international activity: exporters are systematically different from non-exporters. On average, exporters are more productive, larger, more skill and capital intensive and, in general, pay higher wages, and these characteristics precede entry into export markets. Although there is substantial variation across industries, the above results are

\footnotetext{
1 Authors would like to thank for the financial support from the Spanish Ministerio de Economía y Competitividad (ECO2014-58975-P) and Universitat Jaume I (UJI-B2016-53).

2 WTO (2007 and 2015).

${ }^{3}$ See Berthou et al. (2015).

${ }^{4}$ See Bernard and Jensen (1995), Clerides et al. (1998) and Aw et al. (2000).
} 
robust to the inclusion of industry effects in the analysis, and hold for a large number of countries. ${ }^{5}$

From a theoretical point of view, traditional economic models of international trade focus on comparative advantage as the main driver of exports and imports. These models remain useful as comparative advantage explains inter-industry trade and specialization. However, a combination of economies of scale, consumer preferences for variety, and heterogeneous firms (not representative firm) is necessary to account for "intra-industry trade in similar products, reallocations of resources across firms within industries, and innovations in the organization of production within firms" (Melitz and Redding, 2015). These theoretical models rely on differences in firms' productivity to account for their heterogeneity, but in these models productivity should be understood as a catch-all parameter that includes all sources of heterogeneity in revenue relative to factor inputs across firms (differences in technical efficiency, size, factor intensity, labour skills, management practice, firm organization and product quality). ${ }^{6}$

Empirically, one of the more striking findings of this literature is that the majority of firms do not export anything and, in those that do, the export intensity is usually low. However, exports represent a significant percentage of domestic production for most industries and countries. The reason for this apparent paradox is that larger, more productive and more efficient firms export a higher proportion of their sales (Bernard et al., 2003; Brooks, 2006; Eaton et al., 2011; Fariñas and Martín-Marcos, 2007; Ling-Yee, 2004). This view lends support to a positive relationship between export intensity and firms' characteristics. However, some studies fail to find this positive relationship (Castellani, 2002; Gao et al., 2010), and most recent studies even claim there is a more complex relationship among firm efficiency and export intensity. Using data on German manufacturing firms, Wagner (2006) found that the impact of plant characteristics on export activities varies along the conditional size distribution of the export intensity ratio. Crinō and Epifani (2012) used a representative sample of Italian manufacturing firms to replicate all the main empirical regularities of this literature, but found a strong and robust negative correlation between firms' productivity and their share of total exports to low-income destinations. They showed that cross-country heterogeneity of destination markets is responsible for this result. Similarly, in a recent study, Defever and Riaño (2017) used harmonized cross-country firm-level data from the World Bank Enterprise Surveys (WBES) to show that the distribution of export intensity varies tremendously across countries. Likewise, they noted that differences in specific factors of firm destination markets explain most of the observed variation in the distribution of export intensity around the world.

Similarly, on examining the relationship between firms' characteristics and the export market scope some gaps also appear. New evidence from microeconometric studies implies that firms that export to a larger number of foreign markets have to be more productive than firms that serve a smaller number of

\footnotetext{
${ }^{5}$ Different overviews of the literature confirm these findings for a wide range of countries. See Bernard et al. (2007 and 2012), ISGEP (2008), or Wagner (2007 and 2012).

${ }^{6}$ See Melitz and Redding (2015), p. 8.
} 
markets (Verardi and Wagner, 2010). Conversely, some studies that looked into the number of market destinations of exports found that, although entry does not seem a random process, firms do not enter foreign markets according to an exact hierarchy based on their level of efficiency (Eaton et al., 2011). ${ }^{7}$

These conflicting claims suggest a gap in our understanding of the drivers of the relationship between export activity and firms' characteristics. If we agree that heterogeneity is one of the stylized facts of this new approach, we should probably go a step further and ask ourselves whether the relationship between firms' characteristics and their behaviour in foreign markets should be the same for all of them or not. Therefore, in this paper, we analyse how firm characteristics affect key aspects of export behaviour using a semi-parametric technique: the quantile regression. This methodology allows us to obtain information on the relationship between dependent and independent variables at different quantiles. Particularly, we focus on both the intensive margin (export intensity) as well as one of the extensive margins, that is, the number of markets served. By using firm-level data (EFIGE) of European firms in the manufacturing sector, we make two contributions to the literature. ${ }^{8}$ First, we find the existence of heterogeneous effects and nonlinearities in the relationship between export performance and firms' characteristics. Second, our results show that the effects and behaviour of firms' characteristics on export performance largely depend on the export performance measure taken into account: export intensity or export market scope.

The rest of the paper is organized as follows. In the next section, we present a simple model to illustrate the relationship between export performance and firms' characteristics. Section 3 shows the data and some stylized facts. Section 4 describes the econometric methodology. Section 5 presents the estimation results and the last section concludes.

\section{The Underlying Theoretical Framework}

The abovementioned empirical evidence on firm heterogeneity and international trade suggests that a successful theoretical framework, accounting for the new empirical regularities from microdata, should include at least three elements: First, heterogeneity in firms' efficiency within each industry. Second, the existence of variable transport costs between different markets. Third, some type of sunk costs of entry in export markets. ${ }^{9}$ These elements are an

\footnotetext{
${ }^{7}$ Similar results may be found in Lawless (2009), Crinõ and Epifani (2012) or Alguacil et al. (2017).

${ }^{8}$ Although Barba-Navaretti et al. (2011) also analyse the relationship between firms' characteristics and export intensity as well as export market scope, our study differs in two important aspects. Firstly, we use a different set of firms' characteristics. And secondly, we analyse the effects of the regressors on the entire conditional dependent variable by estimating the quantile regression instead of a simple OLS.

${ }^{9}$ Alternatively, Bernard et al. (2003) develop a model with heterogeneous firms (each firm has access to different technology) and Bertrand competition between them, which allows for endogenous variable mark-ups, and allows the theoretical framework to reconcile with the empirical evidence.
} 
essential part of a set of models based on the seminal paper by Melitz (2003). The Melitz model combines firm heterogeneity with a monopolistic competition framework, based on Krugman's (1980) model of scale economies and product differentiation. Additionally, the existence of variable (iceberg-type) transport costs and fixed costs of exporting ensure that only the more productive firms are exporters in equilibrium. In this paper, as the basis for our empirical work, we outline a simple partial equilibrium model based on Helpman et al. (2004), which has many similarities with most of the Melitz-type models developed by this literature. ${ }^{10}$

The basic theoretical framework rests upon monopolistic competition. Each firm in an industry produces a variety of differentiated goods, which can be used as either consumer or intermediate goods. ${ }^{11}$ Varieties are aggregated, both in the utility and production functions, through a CES function (à la Dixit and Stiglitz, 1977) with elasticity of substitution across varieties equal to $\sigma>1$. These preferences imply that the demand in country $j$ for the variety produced by a domestic firm $i$ is given by:

$$
x_{j}(i)=\left(\frac{p_{j}(i)}{P_{j}}\right)^{-\sigma} \frac{E_{j}}{P_{j}},
$$

where $p_{j}(i)$ is the price charged by domestic firm $i$ in country $j, E_{j}$ is gross expenditure spent on differentiated goods in country $j$, and $p_{j}$ is an index of all price varieties associated with CES preferences in country $j$. The first term of the previous expression takes into account the relative prices, while the second represents the level of demand and is exogenous for each individual firm.

On the supply side, firms can enter each industry at home by paying a fixed sunk entry cost. After paying this entry cost, a firm is endowed with a productivity (output per unit of composite input) $\theta$, drawn from a common distribution $G(\theta)$, where $\theta$ is a catch-all parameter that includes all sources of heterogeneity of firms. As firms with the same productivity within each industry behave symmetrically, we index firms in an industry from now onwards by $\theta$ alone. Upon observing $\theta$, a firm may decide to exit and not produce. If it does produce, it must pay an additional fixed overhead cost $f_{h}$ to sell in the domestic market. Moreover, if the firm chooses to export, it must pay an additional fixed cost $f_{j}$ per market. ${ }^{12}$ We assume that $f_{h}<f_{j}$ for all $j$.

The marginal cost of a firm, endowed with productivity $\theta$, to serve the home market is $w / \theta$, where $w$ is the per-unit composite input cost at home. Alternatively, if the firm exports to country $j$, its marginal cost becomes $\tau_{j} w / \theta$, where $\tau_{j} W>1$ is the iceberg transport cost to serve market $j$ through exports. Given

\footnotetext{
${ }^{10}$ See, for example, Lawless (2009), Mayer et al. (2010) or Yeaple (2009). Helpman (2006), Melitz and Redding (2015) or Redding (2011) provided excellent overviews of this literature.

${ }^{11}$ As in Head and Mayer (2004) or Redding and Venables (2004), we consider that consumers may be firms or individuals.

12 These fixed costs include the costs of forming a wholesale and retail distribution network in each market, marketing costs, and so on.
} 
that in this monopolistic competition framework firms are atomistic, each firm treats the elasticity of substitution among varieties, $\theta$, as its own price elasticity (of demand, and the optimal prices set by a firm with productivity $\theta$ are $p_{\mathrm{h}}$ $(\theta)=(\sigma / \sigma-1)(W / \theta)$ at home, and $p_{\mathrm{j}}=\left(\tau_{j} W / \theta\right)$ in export market $j$, where $(\sigma / \sigma-1)$ is the constant mark-up.

This firm will generate revenues equal to

$$
\begin{aligned}
R_{h}(\theta) & =A_{h}\left(\frac{\theta}{w}\right)^{\sigma-1} \text { if it sells in the domestic market, } \\
R_{j}(\theta) & =A_{j}\left(\frac{\theta}{\tau_{j} w}\right)^{\sigma-1} \text { if it exports to market } j,
\end{aligned}
$$

where $A K=\alpha^{\sigma-1} P_{k} \sigma^{-1} E_{k}$ is the mark-up adjusted demand level in country $k$. Thus, the net operating profits earned by a firm with productivity $\theta$ will be

$$
\begin{aligned}
& \pi_{h}(\theta)=(1-\alpha) A_{h}\left(\frac{\theta}{w}\right)^{\sigma-1}-f_{h} \text { from sales in the domestic market, } \\
& \pi_{j}(\theta)=(1-\alpha) A_{j}\left(\frac{\theta}{\tau_{j} w}\right)^{\sigma-1}-f_{j} \quad \text { from exports to market } j,
\end{aligned}
$$

The equilibrium firm revenue and profit functions are increasing with the firm's own productivity $\theta$ and with the size of the destination market of their goods $\left(A_{h}, A_{j}\right)$, and decreasing with input and transport costs $\left(W, \tau_{j}\right)$.

In order to sell profitably to a market (home or foreign), the firm must have a productivity level that exceeds a certain threshold. From (3) and (4) it follows that there are two cut-off levels of productivity necessary for a firm to be operative in the domestic market and to export to country $j$, equal to

$$
\begin{gathered}
\bar{\theta}_{h}=\left(\frac{\sigma f_{h}}{A_{h}}\right)^{\frac{1}{\sigma-1}} w \\
\bar{\theta}_{j}=\left(\frac{\sigma f_{j}}{A_{j}}\right)^{\frac{1}{\sigma-1}} \tau_{j} w
\end{gathered}
$$

Equation (5) defines the threshold of productivity necessary to remain active in the home market. Only firms with productivity above $\bar{\theta}_{h}$ serve the home market, while firms with productivity below $\bar{\theta}_{h}$ expect negative operating profits and then exit the industry. ${ }^{13}$ Similarly, equation (6) shows the productivity threshold determining the entry of domestic firms in market $j$. As the productivity cut-off for exporting will vary across markets, from (6) it is straightforward that more efficient firms (those that have higher productivity) will enter into

\footnotetext{
${ }^{13}$ Note that in this case firms have zero operating profits and make a loss equal to the sunk entry cost.
} 
more markets. The export market scope of firms is related to characteristics of the countries $\left(A_{i}, f_{j}, \boldsymbol{\tau}_{j}\right)$, but also to own firm productivity $(\theta)$. We can rank all markets from the highest to the least attractive (in accordance with their productivity cut-offs), thereby establishing a hierarchy of different markets. More productive exporters will export to more destination markets, and will do so in a precise order. ${ }^{14}$

Additionally, if we assume, as in Helpman et al. (2004), that $\left(\tau_{j}\right)^{\sigma-1} f_{j}>f_{h}$, that is, sufficiently high values of fixed and variable trade costs, in the symmetric case, ${ }^{15}$ with equal demand levels in all countries, then from (5) and (6) it follows that $\bar{\theta}_{h}<\bar{\theta}_{i}$, and only firms endowed with productivities greater than $\bar{\theta}_{j}$ export to market $j$, while those with productivities between $\bar{\theta}_{h}$ and $\bar{\theta}_{h}$ only sell in the domestic market. In this case it is straightforward to show that although both revenue and profit functions are increasing with firms' productivity, $R_{h}(\theta)$ and $\pi_{h}(\theta)$ increase faster than $R_{j}(\theta)$ and $\pi_{h}(\theta)$, respectively, because of the transport costs involved in exporting to country $j$ (remember that $\tau_{j}>1$ ).

In this case, although an improvement in the productivity of a domestic firm increases both domestic and foreign sales, the increase in domestic sales is greater than the increase in any export market. Hence, the relation between domestic and foreign sales (that is, export intensity) of the firms with different productivity depends on the differences in size between domestic and foreign markets, and on the export market coverage of the firm. Again, if the differences in productivity are high enough and the firm is active in a greater number of markets, an improvement in its efficiency is very likely to lead to a higher export intensity.

To summarize, from Melitz-style models it follows that changes in firm characteristics affect their export activity. Firms with higher records in technical efficiency, size, factor intensity, labour skills, management practice, firm organization, and so on will have both a higher market scope, that is, they will export to a greater number of countries, and probably a higher export intensity.

\section{DATA DESCRIPTION AND STYLIZED FACTS}

The firm-level data used in this paper come from the EU-EFIGE/BruegelUniCredit dataset (EFIGE). This database provides quantitative and qualitative information regarding firm characteristics from a representative sample of almost 15,000 surveyed manufacturing firms involved in international activities from seven European economies (Germany, France, Italy, Spain, United King-

\footnotetext{
14 This exact hierarchy of markets is only robust when we make strong theoretical assumptions. In more general settings this result does not hold. See, for example, Alguacil et al. (2017) or Eaton et al. (2011).

15 These assumptions allow us to illustrate, with precision, one of the most popular regularities in the empirical literature on firm heterogeneity and trade, namely that exporters are systematically more productive than nonexporters.
} 
dom, Austria and Hungary) for the period 2017-2019. ${ }^{16}$ Particularly, our sample consists of 9,849 firms that sell their production to third countries, either totally or partially, through exports.

As dependent variables we use two different measures of their export performance: ${ }^{17}$ export intensity (share of exports in total sales) and export market scope (number of markets to which the firm exports). ${ }^{18}$ As exogenous variables, we include a set of different firm characteristics related to export performance. We used TFP as a proxy of firms' productivity. This variable is calculated as the logarithm of the Solow residual of a Cobb-Douglas production function estimated following the semi-parametric algorithm proposed by Levinsohn and Petrin (2003), at the firm level. Size is measured by the number of employees, while capital intensity is the natural logarithm of the capitallabour ratio $(\mathrm{K} / \mathrm{L})$. $R \& D$ is the percentage of the total turnover that the firm has invested in $R \& D$ on average in the last three years (2007-2009). As a measure of firms' internationalization, we also include two variables. On the one hand, we use FDI, which is a dichotomous variable that takes a value of 1 if the firms also have foreign affiliates, and 0 otherwise. On the other hand, we include Import Intensity, measured as the percentage of the intermediate goods purchased from abroad with respect to the total purchased intermediate goods (from anywhere). Finally, we also consider two different variables in relation to the firms' innovation: Product and Process Innovation. Both variables are dichotomous variables that take a value of 1 if the firms carried out any product or process innovations in the years 2007-2009, and 0 otherwise.

Table 1. Descriptive Statistics

\begin{tabular}{lcccc}
\hline Variable & Mean & Std. Dev. & Min. & Max. \\
\hline Export Intensity & 0.32 & 0.28 & 0 & 1 \\
Market Scope & 11.8 & 16.89 & 0 & 200 \\
TFP & -0.05 & 0.53 & -4.79 & 2.95 \\
Size & 76.80 & 113.03 & 10 & 500 \\
K/L & 4.82 & 0.86 & -4.53 & 8.73 \\
R\&D & 0.07 & 0.09 & 0 & 1 \\
FDI & 0.06 & 0.25 & 0 & 1 \\
Import Intensity & 0.29 & 0.27 & 0 & 1 \\
Product Innovation & 0.57 & 0.49 & 0 & 1 \\
Process Innovation & 0.48 & 0.49 & 0 & 1 \\
\hline
\end{tabular}

\footnotetext{
${ }_{16}$ Notice that although EFIGE data cover the years 2007-2009, the data are cross-sectional.

17 Sousa (2004), reviewing the literature regarding the determinants of export performance, concluded that numerical measures such as sales, profit and market are the most widely used concepts of export performance.

${ }^{18}$ Alguacil et al. (2017) already used the concept of market scope to refer to the number of third markets where the firms sell their production.
} 
In Figures 1.1 and 1.2, we plot the histogram of export intensity and market scope, respectively. We can observe that although the percentage of exporters is dramatically reduced when both export intensity and market scope increase, the dispersion differs greatly between them. As can be observed in Figure 1.1, the distribution of export intensity is spread across the sample more than market scope (Figure 1.2). Particularly, we find that almost 55\% of firms export less than $30 \%$ of their output, while only about $10 \%$ of them sell more than $80 \%$ of their products abroad. However, Figure 1.2 shows that market scope is biased to very low numbers of destinations. In this histogram, there are three large columns that represent firms exporting to between 1 and 15 countries (77\% of the total number of exporters), which suggests that the vast majority of firms tend to export to a small number of countries. These findings confirm that there are significant differences in export performance among firms from both perspectives: the share of exports from sales, and the number of markets in which they are present.

\section{Figure 1.1. Histogram OF EXPORT INTENSITY}

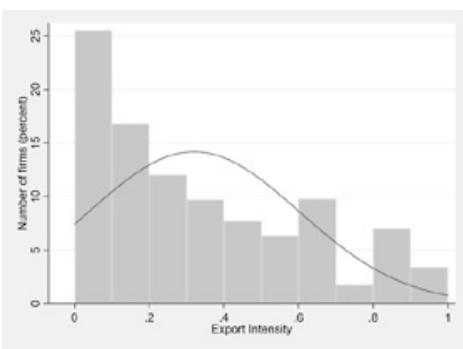

Figure 1.2. Histogram OF EXPORT SCOPE

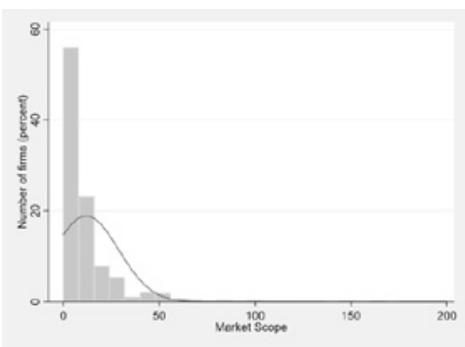

Note: The blue line depicts the normal distribution.

\section{Methodology}

Standard linear regression techniques, such as Ordinary Least Squares (OLS), summarize the average relationship between a set of regressors and the outcome variable based on the conditional mean function $E(y \mid x)$. These methodologies provide only a partial view of the relationship and, therefore, if we are more interested in describing the relationship at different points in the conditional distribution of the dependent variable, as is our case, in order to account for a more complete nature of the relationship between firms' characteristics and their export performance, the quantile regression (Koenker and Bassett, 1978) provides that capability. ${ }^{19}$ The generalization of quantile regres-

\footnotetext{
${ }^{19}$ Focusing only on the central tendency of the variable of interest could be hiding important information about its effects on other points of the distribution of the dependent variable (Maloney et al., 2004).
} 
sion in the economic sphere is still relatively new, ${ }^{20}$ and few contribution dealing with the determinants of export performance at firm level have appeared in the literature to date. ${ }^{21}$

Quantile regression offers important advantages with respect to OLS. While OLS can be inefficient if the errors are highly non-normal, quantile regression is more robust to non-normal errors and outliers, as is our case (see Figures 1.1 and 1.2). Moreover, this methodology also provides a richer characterization of the data, allowing us to consider the impact of a covariate on the entire distribution of the dependent variable, not merely its conditional mean. Therefore, in order to achieve a more comprehensive analysis of the relationships among firms' characteristics and their export performance, in this study we use quantile regressions.

Following Koenker and Bassett (1978), each $\beta$ parameter is estimated by minimizing the absolute sum of the residuals, not the squared sum as in OLS. This is expressed as follows:

$$
\min Q\left(\beta_{q}\right)=\sum_{i: y_{i} \geq x_{i}^{\prime} \beta}^{N} \tau\left|y_{i}-x_{i}^{\prime} \beta_{\tau}\right|+(1-\tau)\left|y_{i}-x_{i}^{\prime} \beta_{\tau}\right|
$$

where $\tau$, which lies within the interval $[0,1]$, represents a specific quantile.

The above function is not differentiable and therefore it cannot be optimized using standard gradient methods. However, this is solved by a linear programming exercise. ${ }^{22}$ Each estimated $\hat{\beta}_{\tau}$ is asymptotically distributed as $N$ $\rightarrow\left(0, \Omega_{\tau}\right)$ where is the variance-covariance matrix of $\hat{\beta}_{\tau}$ for a given $\tau$. We use the algorithm proposed by Frisch-Newton to compute the above fit. ${ }^{23}$ This algorithm is based on the interior point method and suitable for problems with several observations, as in our case. Finally, among the different alternatives to compute standard deviations, we have used the Hall-Sheather bandwidth rule (see Koenker and Hallock, 2001). ${ }^{24}$

\section{EMPIRICAL RESULTS}

In the two cases analysed, as a benchmark, in a first step we estimate several OLS regressions to determine the average relationship between firms' characteristics and export activity. In a second step, quantile regressions are performed in order to observe whether the effects of each firm characteristic

\footnotetext{
20 See Koenker and Hallock (2001).

${ }^{21}$ See, for instance, Wagner (2006) or Alguacil et al. (2017).

22 See Koenker (2005) for a more detailed discussion regarding this technique.

23 See Portnoy and Koenker (1997).

24 Koenker and Hallock (2001) suggested that the discrepancies among different methods are slight, and inference for quantile regression is more robust than for most other forms of inference commonly used in econometrics.
} 
on the two measures of export performance are heterogeneous at different quantiles.

\subsection{EXPORT INTENSITY}

Table 2 depicts the results of the OLS regressions for seven models. These outcomes provide an interesting first approach to evaluate the firm-level determinants of firm export intensity. The results for Model 1 reveal that, as expected, productivity is a positive determinant of the export intensity of European firms, and highly significant. In addition, this result is robust to the inclusion of other characteristics related to firms' efficiency, as well as of industry and country fixed effects (Models 2 to 7). Taken together, the results in Table 2 show a clear pattern regarding the effects of European firms' characteristics on their export intensity. ${ }^{25}$ Specifically, we find that TFP, size, capital and R\&D intensities, a higher degree of internationalization through both FDI and Import activities, as well as engaging in product innovations have a positive and significant effect on the export intensity (Model 6). These outcomes are also robust when we control for country and industry fixed effects (Model 7). ${ }^{26}$ Clearly, our results agree with the theoretical predictions of Melitz-type models: a firm's export intensity is an increasing function of own firms' characteristics.

\footnotetext{
${ }^{25}$ Barba-Navaretti et al. (2011), using the same dataset as us, obtained similar results: firm-specific characteristics are the primary determinants of export intensity. However, previous empirical studies had found contradictory results on this relationship. Many of these studies have been carried out in the areas of business and marketing, and despite the research efforts the lack of clear conclusions about the determinants of export performance is the main result of this literature (see Zou and Stand, 1998; Sousa et al., 2008). In the economics literature, the question has received less attention and the evidence that has been reported, very often in a tangential manner, is also confusing and fragmentary. Thus, for example, Liu et al. (1999) and Castellani (2002) found that labour productivity has no statistically significant effects on export intensity of firms in Taiwan and Italy, respectively. Farinas and Martin-Marcos (2007) observed no clear evidence of the effects of labour productivity in Spain, obtaining different results in different industries. Lachenmaier and Wößmann (2006) found a positive effect of innovation on the export intensity of German firms. Finally, while Benvignati, (1990) and Braunerhjelm (1996) provided evidence that R\&D positively affects export intensity, Kravis and Lipsey (1992) found no significant relationship between them.

${ }^{26}$ Similar results are obtained by Barba-Navaretti et al. (2011) for the case of Size, R\&D and Product Innovation.
} 
TABle 2. Determinants of EXPort Intensity, OLS REGRESSIONS

Dependent variable: export intensity

\begin{tabular}{|c|c|c|c|c|c|c|c|}
\hline \multicolumn{2}{|c|}{ Model 1} & \multirow{2}{*}{$\begin{array}{c}\text { Model } 2 \\
0.125^{* * *} \\
(0.017)\end{array}$} & \multirow{2}{*}{$\begin{array}{c}\text { Model } 3 \\
-0.044 \\
(0.030)\end{array}$} & \multirow{2}{*}{$\begin{array}{c}\text { Model } 4 \\
-0.054^{*} \\
(0.031)\end{array}$} & \multirow{2}{*}{$\begin{array}{c}\text { Model } 5 \\
-0.057 \\
(0.043)\end{array}$} & \multirow{2}{*}{$\begin{array}{c}\text { Model } 6 \\
-0.059 \\
(0.043)\end{array}$} & \multirow{2}{*}{$\begin{array}{c}\text { Model } 7 \\
0.236^{* * *} \\
(0.091)\end{array}$} \\
\hline (Intercept) & $\begin{array}{c}0.333 * * * \\
(0.004)\end{array}$ & & & & & & \\
\hline TFP & $\begin{array}{c}0.073^{* * *} \\
(0.007)\end{array}$ & $\begin{array}{c}0.029 * * * \\
(0.008)\end{array}$ & $\begin{array}{c}0.021^{* *} \\
(0.008)\end{array}$ & $\begin{array}{c}0.021 * * \\
(0.008)\end{array}$ & $\begin{array}{c}0.036^{* * *} \\
(0.011)\end{array}$ & $\begin{array}{c}0.038^{* * * *} \\
(0.011)\end{array}$ & $\begin{array}{c}0.026 * * \\
(0.011)\end{array}$ \\
\hline Size & & $\begin{array}{c}0.053^{* * *} \\
(0.004)\end{array}$ & $\begin{array}{c}0.054^{* * *} \\
(0.004)\end{array}$ & $\begin{array}{c}0.052^{* * *} \\
(0.004)\end{array}$ & $\begin{array}{c}0.048^{* * *} \\
(0.005)\end{array}$ & $\begin{array}{c}0.048^{* * *} \\
(0.005)\end{array}$ & $\begin{array}{c}0.045 * * * \\
(0.006)\end{array}$ \\
\hline $\mathrm{K} / \mathrm{L}$ & & & $\begin{array}{c}0.033 * * * \\
(0.005)\end{array}$ & $\begin{array}{c}0.033^{* * *} * \\
(0.005)\end{array}$ & $\begin{array}{c}0.029 * * * \\
(0.007)\end{array}$ & $\begin{array}{c}0.029 * * * \\
(0.007)\end{array}$ & $\begin{array}{c}0.024 * * * \\
(0.008)\end{array}$ \\
\hline$R \& D$ & & & & $\begin{array}{c}0.029 * * * \\
(0.009)\end{array}$ & $\begin{array}{c}0.049 * * * \\
(0.013)\end{array}$ & $\begin{array}{c}0.040 * * * \\
(0.014)\end{array}$ & $\begin{array}{c}0.051 * * * \\
(0.013)\end{array}$ \\
\hline FDI & & & & & $\begin{array}{c}0.055^{* * *} \\
(0.020)\end{array}$ & $\begin{array}{c}0.053^{* * *} * \\
(0.020)\end{array}$ & $\begin{array}{c}0.045 * * \\
(0.019)\end{array}$ \\
\hline Imp. Int. & & & & & $\begin{array}{c}0.001 * * * \\
(0.000)\end{array}$ & $\begin{array}{c}0.001 * * * \\
(0.000)\end{array}$ & $\begin{array}{c}0.001 * * * \\
(0.000)\end{array}$ \\
\hline Product I. & & & & & & $\begin{array}{c}0.033^{* * *} * \\
(0.012)\end{array}$ & $\begin{array}{l}0.021^{*} \\
(0.012)\end{array}$ \\
\hline Process I. & & & & & & $\begin{array}{c}-0.021 * \\
(0.011)\end{array}$ & $\begin{array}{l}-0.014 \\
(0.011)\end{array}$ \\
\hline N & 4286 & 4286 & 4286 & 4286 & 4286 & 4286 & 4286 \\
\hline $\mathrm{R}^{2}$ & 0.020 & 0.053 & 0.062 & 0.065 & 0.095 & 0.098 & 0.166 \\
\hline $\mathrm{F}_{\text {stat }}$ & $87.25^{* * *}$ & $120.39 * * *$ & $95.74^{* * *}$ & $74.51 * * *$ & $38.73^{* * *}$ & $30.18^{* * *}$ & $18.21^{* * *}$ \\
\hline Country & No & No & No & No & No & No & Yes \\
\hline Industry & No & No & No & No & No & No & Yes \\
\hline
\end{tabular}

Notes: Standard errors are in parentheses. * ${ }^{* *}$ and ${ }^{* * *}$ denote significance at $10 \%, 5 \%$, and $1 \%$ significance levels, respectively.

The results obtained using OLS regressions show how, on average, the different variables included in the model affect export intensity. However, these variables might affect export intensity in a different fashion depending on the level of export intensity of each firm. Therefore, focusing only on the average effect, we might overlook the effects of the potential export intensity drivers on other parts of the distribution of the dependent variable, for instance, in the right (left) tail, where the most (less) export-intensive firms are located. Therefore, in order to deal with this issue, quantile regression is applied in a second step.

Figure 2 shows, graphically, the results of 90 quantile regression estimates from quantiles $\tau=0.05$ to $\tau=0.95$, when we control for all firms' characteristics 
(Model 6, Table 2). ${ }^{27}$ The graphical results shed light on some interesting patterns that remained hidden in our previous OLS estimates. As can be clearly observed, there is significant heterogeneity in the relationship among all the firms' characteristics considered and the export intensity along the conditional distribution of export intensity.

The effect of improvements in TFP on export intensity not only differs along the conditional distribution of export intensity, but it even becomes non-significant at some points in the lowest tail of the distribution. This result suggests that increases in a firm's productivity level have a positive impact on the export intensity only from a certain level of the firm's export intensity. Furthermore, the positive effect is greater for those exporters with high values of export intensity than for those with low levels of export intensity. Thus, the effect on export intensity of one unit change in TFP, keeping other determinants fixed, in the upper part of the distribution is almost double that estimated by OLS for the mean of the distribution.

Regarding size, capital and $R \& D$ intensities, the results show than their effect on export intensity along the distribution of the dependent variable is positive and increasing until the highest quantiles (around $\tau=0.80$ ). From there on, the marginal effect drops sharply, even becoming non-significant in the upper part of the tail for intensity in capital and $R \& D .{ }^{28}$

In relation to the degree of internationalization of firms, we also find differences between the two variables taken into account. While Import Intensity exhibits a pattern similar to that of the TFP, we find that the positive effect on the export intensity of a firm's involvement in FDI activities increases from the lowest tail of the export intensity distribution to the middle of the distribution, when the coefficient starts to decrease and significance is lost after $\tau=0.60$. This result is consistent with the predominance of horizontal FDI from a certain level of firms' exports intensity, and therefore with the existence of a substitution relationship between exports and FDI.

Finally, with regard to firms' innovation characteristics, the results also show a different pattern between product and process innovation activity. On the one hand, being involved in product innovation activities affects the export intensity positively, and the effect increases until the highest quantiles $(\tau=0.60)$, where it remains quite steady. On the other hand, the effects of engaging in process innovation actions are negative, and the marginal effect decreases considerably, becoming non-significant from the medium $(\tau=0.50)$ to the highest quantiles.

Taken together, the results reported in Figure 2 highlight two striking facts. First, heterogeneity matters. Second, there are differences in the patterns of the effects of firms' characteristics on export intensity along their conditional distribution. European firms with a higher level of export

\footnotetext{
${ }^{27}$ Additional information on the interpretation of the figures is provided at the bottom of the figure.

${ }^{28}$ The patterns of these three variables are very similar to the results obtained by Wagner (2001) regarding the effects of firms' size on export intensity.
} 
intensity are more affected by changes in TFP and Import Intensity, while the other firms' characteristics, that is, size, capital and $R \& D$ intensities, or engaging in FDI and product innovation have a greater impact on firms with a medium level of export intensity. These results seem to corroborate that if firms are heterogeneous, we have to expect that there will be different effects of firms' characteristics among different firms (Wagner, 2006). This suggests that different strategies can be used by European firms to increase export intensity, which largely depends on the previous level of export intensity of each firm.

Figure 2: Determinants of Export Intensity, OLS and guantile REgressions for Model 6 DEPENDENT VARIABLE: EXPORT INTENSITY

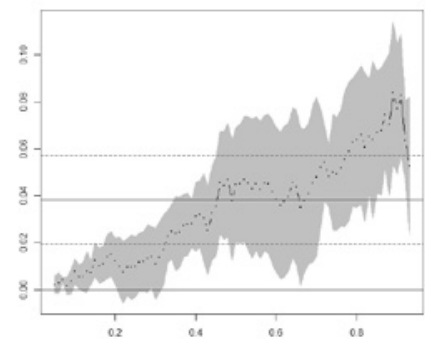

(a)TFP

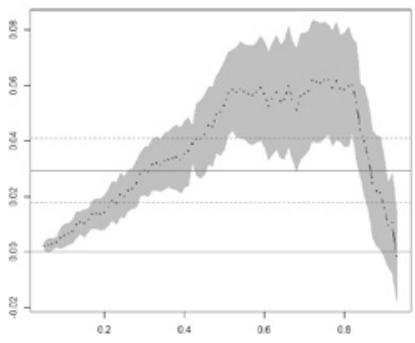

(c) K/L

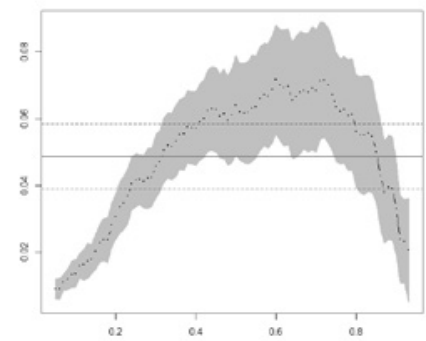

(b)Size

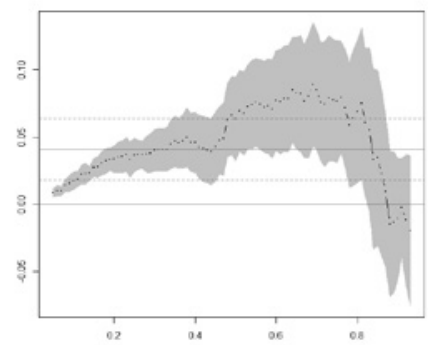

(d)R\&D 


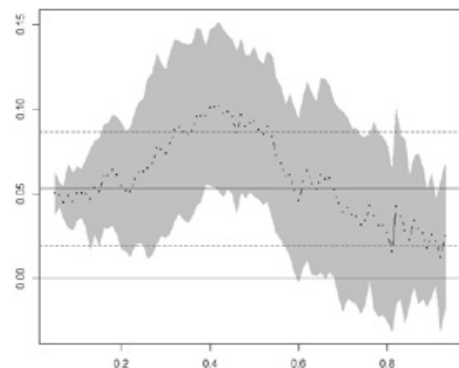

(e)FDI

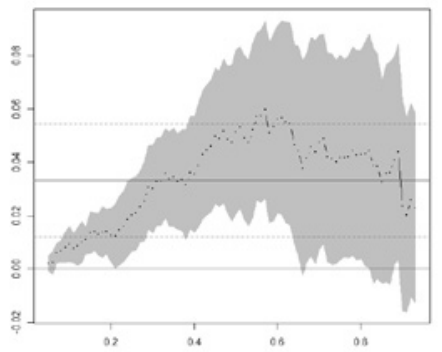

(g)Product I.

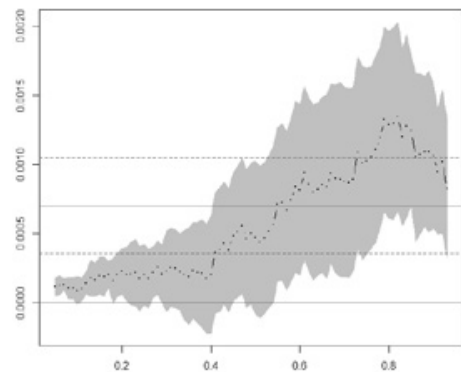

(f)Imp. Int.

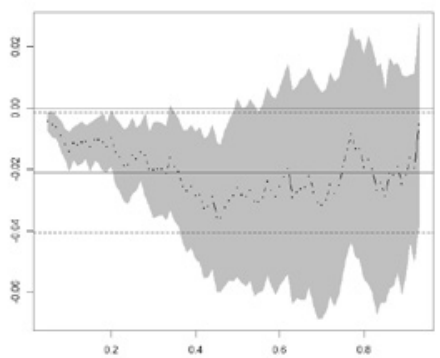

(h)Process I.

Notes: The vertical axis represents the values of the estimated coefficients for each quantile of the dependent variable, represented on the horizontal axis. The non-zero solid line corresponds to the coefficient of the OLS estimation, and the dashed lines correspond to $90 \%$ confidence bands for the OLS estimation. The dashed saw shape line represents the estimated coefficients for each quantile, while the shaded area shows the confidence bands for the quantile regressions at $90 \%$. In those areas where the confidence bands contain zero, the estimated coefficient is non-significant..

\subsection{EXPort MARKet SCOPE}

In Table 3, we show the results of the OLS estimation of the influence of firms' TFP jointly with other firm characteristics that may affect the market scope of firms. Similarly to the export intensity analysis, the OLS results show that the positive effect of productivity (TFP) on the number of markets served by European firms (Model 1) is also robust to the inclusion of additional variables in the more comprehensive models (Models 2 to 7). Furthermore, the vast majority of firms' characteristics considered exert a positive and significant effect on the market scope of firms, as we concluded in the theoretical section. 
Table 3. Determinants of Market Scope, OlS regressions

Dependent variable: market scope

\begin{tabular}{|c|c|c|c|c|c|c|c|}
\hline & Model 1 & Model 2 & Model 3 & Model 4 & Model 5 & Model 6 & Model 7 \\
\hline $\begin{array}{l}\text { (Inter- } \\
\text { cept) }\end{array}$ & $\begin{array}{c}12.521^{* * *} \\
(0.256)\end{array}$ & $\begin{array}{c}-7.417 * * * \\
(1.013)\end{array}$ & $\begin{array}{c}-18.715^{* * *} \\
(1.792)\end{array}$ & $\begin{array}{c}-20.253^{* * *} \\
(1.787)\end{array}$ & $\begin{array}{c}-18.293 * * * \\
(1.795)\end{array}$ & $\begin{array}{c}-18.196 * * * \\
(1.780)\end{array}$ & $\begin{array}{l}-6.892 \\
(4.341)\end{array}$ \\
\hline TFP & $\begin{array}{c}5.991 * * * \\
(0.471)\end{array}$ & $\begin{array}{c}1.794^{* * *} \\
(0.495)\end{array}$ & $\begin{array}{c}1.242 * * \\
(0.497)\end{array}$ & $\begin{array}{c}1.149 * * \\
(0.493)\end{array}$ & $\begin{array}{c}1.274^{* * *} \\
(0.489)\end{array}$ & $\begin{array}{c}1.479 * * * \\
(0.486)\end{array}$ & $\begin{array}{c}1.609 * * * \\
(0.506)\end{array}$ \\
\hline Size & & $\begin{array}{c}5.144^{* * *} \\
(0.253)\end{array}$ & $\begin{array}{c}5.215^{* * *} \\
(0.252)\end{array}$ & $\begin{array}{c}4.849 * * * \\
(0.253)\end{array}$ & $\begin{array}{c}4.188 * * * \\
(0.262)\end{array}$ & $\begin{array}{c}4.087^{* * *} * \\
(0.262)\end{array}$ & $\begin{array}{c}3.843^{* * *} \\
(0.277)\end{array}$ \\
\hline $\mathrm{K} / \mathrm{L}$ & & & $\begin{array}{c}2.242 * * * \\
(0.294)\end{array}$ & $\begin{array}{c}2.203 * * * \\
(0.292)\end{array}$ & $\begin{array}{c}2.063 * * * \\
(0.289)\end{array}$ & $\begin{array}{c}1.923 * * * \\
(0.288)\end{array}$ & $\begin{array}{c}1.342 * * * \\
(0.326)\end{array}$ \\
\hline$R \& D$ & & & & $\begin{array}{c}4.522 * * * \\
(0.532)\end{array}$ & $\begin{array}{c}4.185 * * * \\
(0.529)\end{array}$ & $\begin{array}{c}2.725^{* * *} * \\
(0.561)\end{array}$ & $\begin{array}{c}2.230 * * * \\
(0.568)\end{array}$ \\
\hline FDI & & & & & $\begin{array}{c}8.091 * * * \\
(0.966)\end{array}$ & $\begin{array}{c}7.836^{* * *} * \\
(0.959)\end{array}$ & $\begin{array}{c}7.299 * * * \\
(0.953)\end{array}$ \\
\hline Imp. Int. & & & & & $\begin{array}{c}1.407 * * * \\
(0.516)\end{array}$ & $\begin{array}{c}1.250^{* *} \\
(0.513)\end{array}$ & $\begin{array}{c}1.671^{* * * *} \\
(0.520)\end{array}$ \\
\hline $\begin{array}{l}\text { Product } \\
\text { l. }\end{array}$ & & & & & & $\begin{array}{c}4.426 * * * \\
(0.523)\end{array}$ & $\begin{array}{c}3.877^{* * * *} \\
(0.522)\end{array}$ \\
\hline $\begin{array}{l}\text { Process } \\
\text { I. }\end{array}$ & & & & & & $\begin{array}{c}-0.909 * \\
(0.492)\end{array}$ & $\begin{array}{l}-0.594 \\
(0.492)\end{array}$ \\
\hline N & & 4266 & 4266 & 4266 & 4266 & 4266 & 4266 \\
\hline $\mathrm{R}^{2}$ & & 0.121 & 0.133 & 0.147 & 0.163 & 0.177 & 0.201 \\
\hline $\mathrm{F}_{\text {stat }}$ & & $294.15^{* * *}$ & $218.05^{* * *}$ & $184.33 * * *$ & $138.38 * * *$ & $114.45^{* * *}$ & $44.48 * * *$ \\
\hline Country & No & No & No & No & No & No & Yes \\
\hline Industry & No & No & No & No & No & No & Yes \\
\hline
\end{tabular}

Notes: Standard errors are in parentheses. ${ }^{*},{ }^{* *}$ and $* * *$ denote significance at 10\%, 5\%, and $1 \%$ significance levels, respectively.

However, the quantile regression results for the export market scope of European firms (Figure 3) present some differences with respect to the patterns established in the case of export intensity. As we can observe, Figure 3 shows a clear homogeneous pattern for all independent variables considered. We found that increases in firms' TFP, size, capital or R\&D intensity, being involved in other internationalization activities, such as import and FDI, as well as being involved in product innovation activities, have a positive and increasing effect on the export market scope of European firms along the conditional distribution of the dependent variable. ${ }^{29}$ In all cases, the effect of improvements in firms' characteristics on the number of export markets served by the firm is

${ }^{29}$ As with export intensity, from the perspective of the number of export markets where the firm is active, there is no clear significant pattern associated with the development of process innovations. In both cases the inclusion of variables such as TFP or spending on R\&D is probably responsible for these results. 
lower in the left tail of the distribution, where the firms with the lowest export market scope are located, than in the right tail, where those exporters with the higher market scope values are located. This result suggests that there is some kind of learning-by-exporting, which allows those firms with higher levels of market scope to obtain an advantage in order to be more competitive internationally than their counterparts with lower market scope.

Again, from the point of view of the effect of improving certain characteristics of the firm on the number of export markets in which it is active, heterogeneity matters, and there are systematic differences in the effect of the firms' characteristics on the export market scope along their conditional distribution.

Figure 3: Determinants of Export Performance, OlS and quantile regressions for Model 6

DEPENDENT VARIABLE: EXPORT MARKET SCOPE

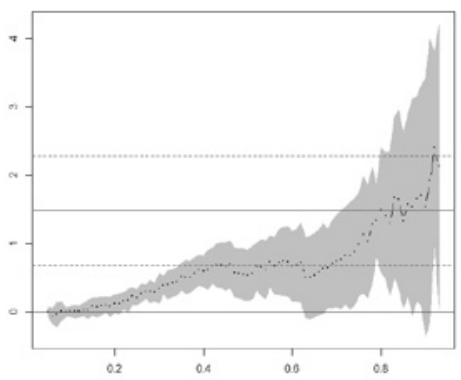

(a)TFP

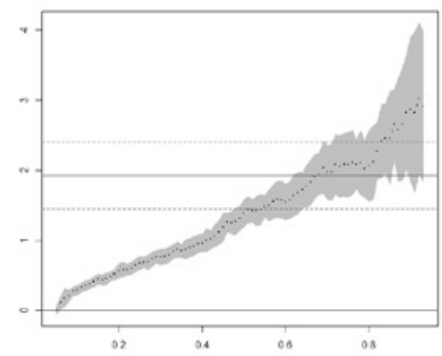

(C) K/L

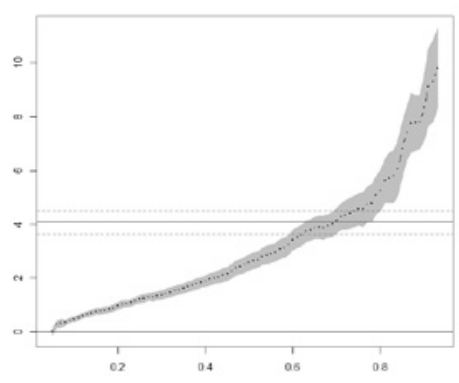

(b)Size

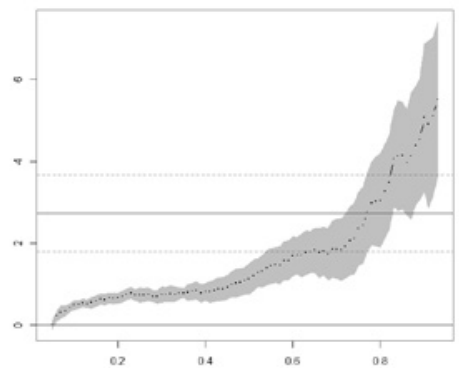

(d)R\&D 


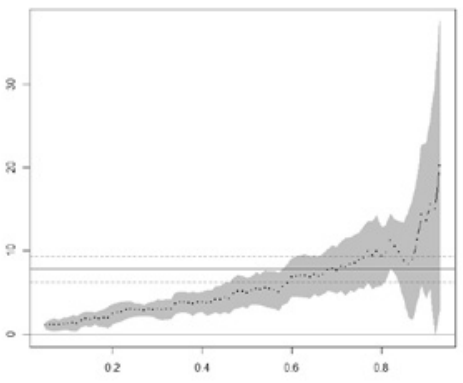

(e)FDI

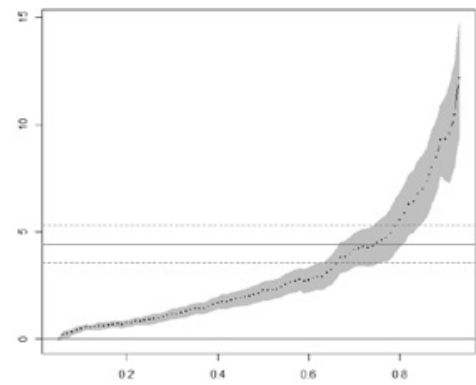

(g)Product I.

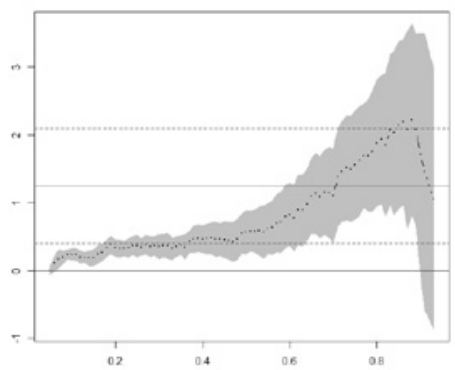

(f)Imp. Int.

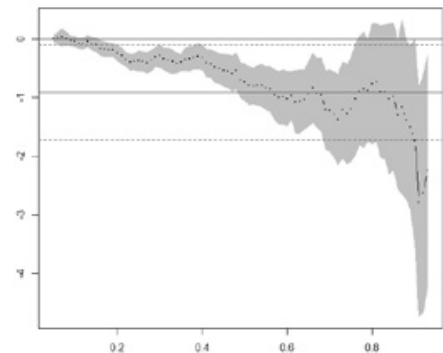

(h)Process I.

Notes:The vertical axis represents the values of the estimated coefficients for each quantile of the dependent variable, represented on the horizontal axis. The non-zero solid line corresponds to the coefficient of the OLS estimation, and the dashed lines correspond to $90 \%$ confidence bands for the OLS estimation. The dashed saw shape line represents the estimated coefficients for each quantile, while the shaded area shows the confidence bands for the quantile regressions at $90 \%$. In those areas where the confidence bands contain zero, the estimated coefficient is non-significant.

\section{CONCLUSIONS}

This study focuses on the relationship between firms' characteristics and export activity. Particularly, we analyse the effects of different measures of firms' efficiency and internationalization on export intensity (intensive margin) and market scope (extensive margin) for the case of European firms in the manufacturing sector.

While, from a theoretical point of view, the literature has found a systematic relationship between firms' characteristics and both measures of export activity, the empirical studies have found contradictory results in some cases. These suggest that there is a gap in our understanding of the determinants of 
this relationship, warranting further research in order to provide valuable implications for both policymakers and firms' managers in order to gain a better knowledge of export success.

Firstly, we estimate different OLS models in order to analyse the above relationship. Our results show that the effects of productivity, size, capital intensity, $R \& D$, level of internationalization and product innovation have a positive effect on both export intensity and market scope. Although OLS regressions provide useful insights, they focus on the average effects and, thus, this methodology sheds no light on the effects of the firms' characteristics in other particular parts of the conditional distribution of the dependent variable. Therefore, secondly, we estimate the quantile regression, which enables us to obtain a more comprehensive analysis of the relationship between export activity and firms' characteristics among the whole distribution. Moreover, this methodology allows us to observe that if we consider exporters in an industry as being heterogeneous, we have reasons to suspect that the effects of the firm characteristics on firms' export performance do not need to be equal for all firms.

Particularly, the quantile regression results corroborate the existence of heterogeneous effects and nonlinearities among firms' characteristics on both export intensity and market scope, along the conditional distribution of the dependent variable considered. In addition, these heterogeneous effects are different for each of the endogenous variables considered. Specifically, we find that while improvements in all firms' characteristics considered exert a positive effect on the market scope of European exporting firms, the effect is increasing from the lowest to the highest quantiles of firms' market scope. However, although the relationship between firms' characteristics and their export intensity is still positive, we obtain an inverted-U shaped relationship along the conditional distribution of export intensity for some variables considered (size, capital intensity and $R \& D$ ). These results suggest that firms' characteristics have different effects not only depending on the export activity measure taken into account, but also depending on the previous level of export activity of each firm.

\section{REFERENCES}

Alguacil, M., Martī, J., and Orts, V. (2017): Firm Heterogeneity and the Market Scope of European Multinational Activity. International Review of Economics \& Finance, 51, 645-659.

Aw, B-Y., Chung, S., and Roberts, M. (2000): Productivity and Turnover in the Export Market: Micro-Level Evidence from Republic of Korea and Taiwan. The World Bank Economic Review 14, 65-90.

Barba-Navaretti, G., Bugamelli, M., Schivardi, F., Altomonte, C., Horgos, D., and Maggioni, D. (2011): The Global Operations of European Firms-The Second EFIGE Policy Report. Bruegel Blueprint Series. Vol XII. Bruegel. 
Benvignati, A. M. (1990): Industry Determinants and "Differences" in US Intrafirm and Arms-Length Exports. The Review of Economics and Statistics, 481-488.

Bernard, A.B., Eaton, J., Jensen, J.B. and Kortum, S. (2003): Plants and Productivity in International Trade. American Economic Review, 93 (4): 1268 1290.

Bernard, A.B., and Jensen, J.B. (1995): Exporters, Jobs, and Wages in U.S. Manufacturing: 1976-1987. Brookings Papers on Economic Activity. Microeconomics, 67-119.

Bernard, A.B., Jensen, J.B., Redding, S.J., and Schott, P.K. (2007): Firms in International Trade. Journal of Economic Perspectives, 21 (3): 105-30.

Bernard, A.B., Jensen, J.B., Redding, S.J., and Schott, P.K. (2012): The Empirics of Firm Heterogeneity and International Trade. Annual Review of EConomics, 4: 283-313.

Berthou, A., Dhyne, E., Bugameli, M., Cazacu, A.M., Demian, C.V., Harasztosi, P., Lalinsky, T., Merikúll, J., Oropallo, F., and Soares, A.C. (2015): Assessing European Firms' Exports and Productivity Distributions: the CompNet Trade Module. European Central Bank Working Paper, 1788 /May 2015.

Braunerhjelm, P. (1996): The Relation between Firm-Specific Intangibles and Exports. Economics Letters, 53(2), 213-219.

Castellani, D. (2002): Export Behavior and Productivity Growth: Evidence from Italian Manufacturing Firms. Review of World Economics, 138(4), 605-628.

Clerides, S., Lach, S. and Tybout, J. (1998): Is Learning by Exporting Important? Micro-Dynamic Evidence from Colombia, Mexico and Morocco. Quarterly Journal of Economics, 113: 903-948.

Crinō, R., and Edifani, P. (2012): Productivity, Quality and Export Behaviour. The Economic Journal, 122, 1206-1243.

Defever, F., and Riaño, A. (2017): Twin Peaks. CEP Discuccion Paper No 1505. Centre for Economic Performance. London School of Economics and Political Science.

Dixit, A.K., and Stiglitz, J.E. (1977): Monopolistic Competition and Optimum Product Diversity. American Economic Review, 67(3), 397-308.

Eaton, J., Kortum, S., and Kramarz, F. (2011): An Anatomy of International Trade: Evidence from French Firms. Econometrica, 79(5), 1453-1498.

Farinas, J. C., and Martín-Marcos, A. (2007): Exporting and Economic Performance: Firm-level Evidence of Spanish Manufacturing. The World Economy, 30(4), 618-646.

Gao, G. Y., Murray, J. Y., Kotabe, M., and Lu, J. (2010): A Strategy Tripod Perspective on Export Behaviors: Evidence from Domestic and Foreign Firms Based in an Emerging Economy. Journal of International Business Studies, 41, 377-396.

Head, K., and Mayer, T. (2004): Market Potential and the Location of Japanese Investment in the European Union. The Review of Economics and Statistics 86 (4), 959-972. 
Helpman, E. (2006): Trade, FDI, and the Organization of Firms. Journal of EConomic Literature. XLIV (Sept.), 589-630.

Helpman, E., Melitz, M. J., and Yeaple, S.R. (2004): Export versus FDI with Heterogeneous Firms. American Economic Review, 94(1), 300-316.

ISGEP (International Study Group on Exports and Productivity) (2008): Understanding Cross-Country Differences in Export Premia: Comparable Evidence for 14 Countries. Review of World Economics, 144 (4): 596-634.

Koenker, R. and Bassett, G. (1978): Regression Quantiles. Econometrica, 46(1), 33-50.

Koenker, R. and Hallock, K. F. (2001): Quantile Regression. Journal of Economic Perspectives, 15(4), 143-156.

Koenker, R. (2005): Quantile Regression. Cambridge University Press, New York.

Kravis, I. B., and Lipsey, R. E. (1992): Sources of Competitiveness of the United States and of its Multinational Firms. The Review of Economics and Statistics, 193-201.

Krugman, P. (1980): Scale Economies, Product Differentiation, and the Pattern of Trade. The American Economic Review, 70(5), 950-959.

Lachenmaier, S., and Wößmann, L. (2006): Does Innovation cause Exports? Evidence from Exogenous Innovation Impulses and Obstacles using German Micro Data. Oxford Economic Papers, 58(2), 317-350.

Lawless, M. (2009): Firm Export Dynamics and the Geography of Trade. Journal of International Economics, 77(2), 245-254.

Levinsohn, J., and Petrin, A. (2003): Estimating Production Functions using Inputs to control for Unobservables. The Review of Economic Studies, 70(2), 317-341.

Ling-Yee, L. (2004): An Examination of the Foreign Market Knowledge of Exporting Firms based in the People's Republic of China: Its Determinants and Effect on Export Intensity. Industrial Marketing Management, 33(7), $561-572$.

Liu, J. T., Tsou, M. W., and Hammitt, J. K. (1999): Export Activity and Productivity: Evidence from the Taiwan Electronics Industry. Review of World Economics, 135(4), 675-691.

Maloney, W. F., Cunningham, W. V., and Bosch, M. (2004): The Distribution of Income Shocks during Crises: An Application of Quantile Analysis to Mexico, 1992-95. The World Bank Economic Review, 18(2), 155-174.

Mayer, T., Mejean, I. and Nefussi, B., (2010): The Location of Domestic and Foreign Production Affiliates by French Multinational Firms. Journal of Urban Economics, 68(2), 115-128.

Melitz, M.J., (2003): The Impact of Trade on Intra Industry Reallocations and Aggregate Industry Productivity. Econometrica, 71 (6), 1695-1725.

Melitz, M.J., and Redding, S.J. (2015): Heterogeneous Firms and Trade. In G. Gopinath, E. Helpman and K. Rogoff, ed. Handbook of International Economics, Amsterdam: Elsevier. Vol. 4 (ch. 1), 1-54. 
Portnoy, S., and Koenker, R. (1997): The Gaussian Hare and the Laplacian Tortoise: Computability of Squared-Error versus Absolute-Error Estimators. Statistical Science, 12(4), 279-300.

Redding, S.J. (2011): Theories of Heterogeneous Firms and Trade. Annual Review of Economics. 2(1), 77-105.

Redding, S., and Venables, A.J. (2004): Economic Geography and International Inequality. Journal of International Economics. 62(1), 53-82.

Sousa, C. (2004): Export Performance Measurement: an Evaluation of the Empirical Research in the Literature. Academy of Marketing Science Review, Vol. 2004 (9), 1-21.

Sousa, C. M., Martínez-López, F. J., and Coelho, F. (2008): The Determinants of Export Performance: A Review of the Research in the Literature between 1998 and 2005. International Journal of Management Reviews, 10(4), 343-374.

Verardi, V., and Wagner, J. (2012): Productivity Premia for German Manufacturing Firms Exporting to the Euro-Area and Beyond: First Evidence from Robust Fixed Effects Estimations. The World Economy, 35(6), 694-712

Wagner, J. (2001): A Note on the Firm Size-Export Relationship. Small Business Economics, 17(4), 229-237.

Wagner, J. (2006): Export Intensity and Plant Characteristics: What Can We learn from Quantile Regression? Review of World Economics, 142(1), 195203.

Wagner, J. (2007): Exports and Productivity: A Survey of the Evidence from Firm Level Data. The World Economy, 30 (1): 60-82.

Wagner, J. (2012): International Trade and Firm Performance: A Survey of Empirical Studies since 2006, Review of World Economics, 148 (2), 235-267.

WTO (2007): World Trade Report 2007, World Trade Organization.

WTO (2015): International Trade Statistics 2015, World Trade Organization.

Yeaple, S. R. (2009): Firm Heterogeneity and the Structure of US Multinational Activity. Journal of International Economics, 78(2), 206-215.

Zou, S. and Stan, S. (1998): The Determinants of Export Performance: a Review of the Empirical Literature between 1987 and 1997. International Marketing Review, 15(5), 333-356. 